\title{
TINGKAT PENGETAHUAN IBU TENTANG PENGGUNAAN ANTIBIOTIK PADA MASA KEHAMILAN TERHADAP PEWARNAAN GIGI ANAK BALITA DI KELURAHAN LAU CIH KECAMATAN MEDAN TUNTUNGAN
}

\author{
Ngena Ria \\ Jurusan Keperawatan Gigi
}

\begin{abstract}
Abstrak
Antibotik merupakan zat-zat kimia yang dihasilkan oleh fungsi dan bakteri yang memiliki khasiat mematikan atau menghambat pertumbuhan kuman sedangkan toksitasnya bagi manusia relatif rendah. Penelitian bersifat deskriptif dengan metode survy yang bertujuan untuk mengetahui seberapa besar tingkat pengetahuan ibu tentang penggunaan antibiotik pada masa kehamilan. Sampel adalah ibu hamil yang berjumlah 30 orang. Data diperoleh dengan cara pengisian kuesioner yang di Kelurahan Lau Cih Kecamatan Medan Tuntungan. Hasil penelitian menunjukkan bahwa $20 \%$ ibu memiliki pengetahuan baik, $10 \%$ ibu memiliki pengetahuan sedang dan tidak ada $(0 \%)$ ibu yang memiliki pengetahuan buruk mengenai tingkat pengetahuan tentang penggunaan antibiotik pada masa kehamilan.
\end{abstract}

Kata Kunci : Pengguna Antibiotik, masa kehamilan, pewarnaan gigi anak

\section{Latar Belakang}

Kesehatan merupakan suatu keadaan dari badan, jiwa dan sosial, dimana seseorang hidup produktif secara sosial dan ekonomis. Pembangunan sektor kesehatan nasional diarahkan untuk meningkatkan derajat kesehatan masyarakat yang optimal, meningkatkan gizi, membudayakan sikap hidup bersih dan sehat serta meningkatkan mutu dan mempermudah pelayanan kesehatan yang harus terjangkau oleh seluruh masyarakat.

Kesehatan gigi dan mulut merupakan bagian integral dari kesehatan umum khususnya rongga mulut. Rongga mulut dikatakan sehat apabila mempunyai susunan gigi yang rapi, teratur, terhindar dari penyakit jaringan keras gigi dan jaringan periodontal.

Pemeliharaan kesehatan gigi dan mulut pada anak sangat penting, sebab pada masa anak dalam kandungan selama enam bulan gigi susu berwarna putih seperti susu, sehingga disebut gigi susu. Gigi susu mempunyai pengaruh yang cukup besar terhadap pertumbuhan gigi tetap sebagai penggantinya, bila gigi susu tidak dirawat maka akan merugikan pertumbuhan gigi tetap.

Antibiotik merupakan zat kimia yang dihasilkan oleh mikroorganisme hidup, terutama fungsi dan bakteri yang memiliki kemampuan mematikan atau menghambat pertumbuhan jumlah bakteri dan virus, sedangkan tingkat toksik bagi manusia relatif kecil. Pemberian antibiotik yang tidak tepat sejak usia dini dapat menimbulkan elergi di masa yang akan datang.

Pengetahuan merupakan hasil tahu dari manusia dan terjadi setelah seseorang melakukan penginderaan terhadap suatu objek tertentu. Pengetahuan kebersihan gigi dan mulut meliputi tentang menyikat gigi, makanan yang mempengaruhi kesehatan gigi serta pengetahuan tentang kapan pemeriksaan gigi secara periodik dilakukan.

Pengetahuan orang tua, khususnya ibu tentang penggunaan antibiotik pada masa kehamilan sangat berperan penting terhadap kesehatan gigi anak balita, terutama pada masa pertumbuhan gigi susu yang berpengaruh terhadap pertumbuhan gigi tetap sebagai pengganti gigi susu.

Adanya gangguan email pada benih gigi tetap akibat infeksi gigi susu yang mengenai benih gigi dibawahnya juga dapat menimbulkan kelainan pada email gigi yang menyebabkan warna gigi tetap menjadi kecoklatan atau abu-abu, tergantung dari frekuensi pemakaian obat selama pembentukan gigi.

Berdasarkan uraian di atas, penulis ingin mengetahui tingkat pengetahuan ibu tentang penggunaan antibiotik pada masa kehamilan terhadap pewarnaan gigi anak balita di Kelurahan Lau Cih Kecamatan Medan Tuntungan

\section{Perumusan Masalah}

Berdasarkan latar belakang masalah tersebut, penulis ingin melakukan penelitian tentang bagaimana tingkat pengetahuan ibu tentang penggunaan antibiotik pada masa kehamilan terhadap pewarnaan gigi anak balita di Kelurahan Lau Cih Kecamatan Medan Tuntungan.

\section{Tujuan Penelitian}

Untuk mengetahui tingkat pengetahuan ibu tentang penggunaan antibiotik pada masa kehamilan terhadap pewarnaan gigi anak balita di Kelurahan Lau Cih Kecamatan Medan Tuntungan.

1. Untuk mengetahui pengetahuan ibu tentang waktu penggunaan antibiotik pada masa kehamilan terhadap pewarnaan gigi anak balita.

2. Untuk mengetahui pengetahuan ibu tentang dosis/ukuran penggunaan antibiotik pada masa kehamilan terhadap pewarnaan gigi anak balita. 
3. Untuk mengetahui jenis antibiotik yang di gunakan pada masa kehamilan pada pewarnaan gigi anak balita.

\section{Manfaat Penelitian}

1. Hasil penelitian ini diharapkan dapat menambah wawasan dan pengetahuan bagi ibu-ibu Warga Lau Cih kecamatan Medan Tuntungan.

2. Hasil penelitian ini diharapkan dapat menjadi bahan masukan bagi ibu-ibu Warga Lau Cih Kecamatan Medan Tuntungan dalam menjaga kesehatan gigi anak balita.

3. Hasil penelitian ini diharapkan dapat menambah wawasan pengetahuan bagi peneliti dan sebagai masukan bagi peneliti lain.

\section{Karangka Konsep}

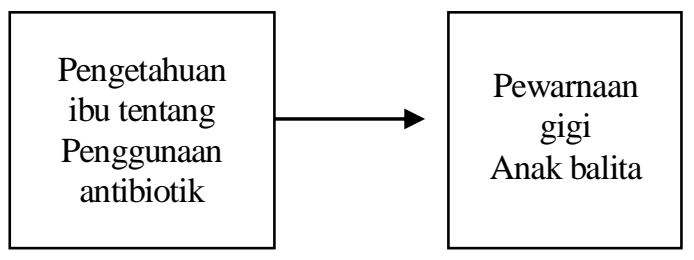

\section{Defenisi Operasional}

1. Tingkat pengetahuan ibu tentang penggunaan antibiotik pada masa kehamilan adalah pemahaman responden mengenai tingkat pengetahuan tentang penggunaan antibiotik yang digolongkan pada kata gori baik, sedang dan buruk berdasarkan kuesioner.

2. Ibu adalah yang memiliki balita di Kelurahan Lau Cih Kecamatan Medan Tuntungan.

3. Pewarnaan gigi anak balita adalah perubahan warna pada gigi anak balita dikarenakan pemberian antibiotik yang berlebihan .

4. Pewarnaan adalah perubahan warna pada gigi dikarenakan pemberian antibiotik yang berlebihan pada masa kehamilan.

\section{Jenis Penelitian}

Jenis penelitian yang dilakukan adalah penelitian deskriptif dengan metode survy yang dilakukan pemeriksaan langsung pada ibu yang memiliki balita dengan tujuan untuk mengetahui gambaran mengenai pengetahuan ibu tentang penggunaan antibiotik pada masa kehamilan terhadap pewarnaan gigi anak balita di Kelurahan Lau Cih kecamatan Medan Tuntungan

\section{Populasi}

Populasi adalah kumpulan elemen-elemen yang memiliki sejumlah sifat-sifat tertentu. Populasi adalah ibuibu yang memiliki anak balita di Kelurahan Lau Cih Kecamatan Medan Tuntungan.

\section{Sampel}

Sampel adalah sebagian dari keseluruhan objek yang diteliti dan dianggap mewakili seluruh populasi.
Dalam penelitian ini jumlah sampel penelitian sebanyak 30 orang.

Kriteria inklusi sampel yaitu :

1. Ibu memiliki anak balita

2. Masa hamil pernah menggunakan antibiotik

\section{Jenis dan cara penelitian}

Data yang diambil dalam penelitian adalah data primer dengan memberikan kuesioner yang secara langsung diberikan pada ibu yang mempunyai anak balita. Sebelum kuesioner dibagikan, peneliti terlebih dahulu menjelaskan masing-masing butir pertanyaan kepada ibu yang mempunyai anak balita. Selain itu, peneliti membagikan daftar kuesioner untuk diisi. Isi dari kuesioner diupayakan untuk memperoleh data seberapa besar gambaran tingkat pengetahuan ibu terhadap pewarnaan gigi anak balita. Setelah kuesioner diisi maka peneliti mengambil kembali hasil kuesioner.

Bentuk kuesioner yang diambil dalam penelitian adalah bentuk pertanyaan berupa multiple choice yang terdiri dari dua pilihan dan masing-masing mempunyai nilai tertentu :

1. Untuk menjawab yang benar, skor nilai 1 (satu)

2. Untuk menjawab yang salah, skor nilainya 0 (nol)

Rumus untuk mencari kuesioner

RUMUS = Sekor maksimum-skor minimum 3

Maka kriteria pengetahuan yang diperoleh dengan penggenapan adalah:

$$
\begin{aligned}
& \text { - Baik } \quad=7-10 \\
& \text { - } \text { Sedang }=4-6 \\
& \text { - Buruk = } 0-3 \\
& \text { Bahan/instrument yang digunakan adalah : } \\
& \text { - Kuesioner }
\end{aligned}
$$

\section{Pengolahan Data Dan Analisa Data}

Setelah data dikumpulkan dilakukan analisa data dengan cara manual dan disajikan bentuk tabel distribusi frekuensi. Pengolahan data dan analisa data meliputi:

1. Menghitung tingkat pengetahuan ibu tentang pemberian antibiotik terhadap pewarnaan gigi anak balita di Kelurahan Lau Cih Kecamatan Medan Tuntungan Tahun 2011.

2. Memeriksa pewarnaan gigi pada anak balita di Kelurahan Lau Cih Kecamatan Medan Tuntungan.

\section{Hasil Penelitian}

Berdasarkan hasil penelitian yang dilakukan pada 30 orang ibu-ibu yang mempunyai anak balita di Kelurahan Lau Cih Kecamatan Medan Tuntungan, maka didapat hasil sebagai berikut :

Tabel 4.1 Distribusi Frekuensi Karakter Ibu berdasarkan Umur dan Tingkat Pendidikan 


\begin{tabular}{|l|l|l|l|}
\hline No & Karakteristik ibu & $\mathbf{n}$ & $\mathbf{( 0 \% )}$ \\
\hline \multirow{1}{*}{2} & Berdasarkan umur & & \\
& $-\quad 24-30$ & 10 & 33,33 \\
& $-\quad 31-37$ & 10 & 33,33 \\
& $-\quad 38-44$ & 8 & 26,66 \\
& $-\quad 45-50$ & 2 & 6,66 \\
& Berdasarkan tingkat & & \\
& pendidikan & & \\
& $-\quad$ SD & 2 & \\
& $-\quad$ SMP & 5 & 6,66 \\
& $-\quad$ SLTA & 16 & 16,66 \\
& $-\quad$ Perguruan tinggi \\
& (D3,S1) & 7 & 53,33 \\
& & & 23,33 \\
& & & \\
\hline
\end{tabular}

Dari tabel dapat diketahui bahwa dari 30 orang ibuibu yang berumur 24-30 adalah 10 orang (33,33\%), memiliki umur 31-37 adalah 10 orang (33,33\%), memiliki umur 38-44 adalah 8 orang $(26,66 \%)$ dan memiliki umur $45-50$ adalah 2 orang $(6,66 \%)$. Sedangkan yang memiliki tingkat pendidikan SD adalah 2 orang $(6,66 \%)$, memiliki pendidikan SMP adalah 5 orang $(16,66 \%)$, memiliki pendidikan SLTA adalah 16 orang $(53,33 \%)$ dan memiliki pendidikan D3-S1 adalah 7 orang $(23,33 \%)$

Tabel 4. 2 Distribusi Frekuensi Tingkat Pengetahuan Ibu tentang penggunaan Antibiotik pada masa kehamilan terhadap pewarnaan gigi anak balita di Kelurahan Lau Cih Kecamatan Medan Tuntungan.

\begin{tabular}{|l|l|l|l|}
\hline No & $\begin{array}{l}\text { Tingkat } \\
\text { Pengetahuan }\end{array}$ & $(\mathbf{n})$ & $(\boldsymbol{\%})$ \\
\hline 1 & Baik & 20 & 66.66 \\
\hline 2 & Sedang & 10 & 33,33 \\
\hline 3 & Buruk & 0 & 0 \\
\hline & Jumlah & 30 & 100 \\
\hline
\end{tabular}

Dari tabel diatas dapat diketahui bahwa dari 30 ibu-ibu yang mempunyai anak balita di kelurahan Lau Cih Kecamatan Medan Tuntungan, paling banyak mempunyai tingkat pengetahuan baik yaitu sebanyak 20 orang $(66,66 \%)$, memiliki tingkat pengetahuan sedang 10 orang dan $(33,33 \%)$ dan tidak ada ibu-ibu yang memiliki tingkat pengetahuan buruk $(0 \%)$

\section{PEMBAHASAN}

Hasil penelitian yang diperoleh menunjukkan bahwa tingkat pengetahuan ibu adalah baik $(56,66 \%)$ dan tidak ada ibu-ibu yang tingkat pengetahuannya buruk $(0 \%)$. Hal ini kemungkinan disebabkan karena sebagian besar ibu $(76,66 \%)$ sudah memiliki pendidikan SMA ke atas.
Sebagian ibu $(46,66 \%)$ sudah mengetahui tentang antibiotik, sebagian ibu $(70 \%)$ pada masa hamil menggunakan antibiotik saat bila sakit, namun masih ada ibu $(60 \%)$ yang tidak mengetahui kegunaan antibiotik. Dari hasil penelitian yang diperoleh bahwa sebagian ibu (30\%) tidak mengetahui bahwa tetrasiklin salah satu jenis antibiotik yang dapat menyebabkan perubahan warna gigi anak. Antibiotik merupakan obat yang dapat membunuh bakteri penyebab infeksi. Merupakan obat daftar generik, pemakaian harus berdasarkan resep dokter. Penyakitpenyakit yang dapat disembuhkan dengan menggunakan antibiotik adalah penyakit pilek, batuk berkepanjangan selama lima hari, TBC, infeksi saluran kemih, penyakit tyhpus dan diare yang disertai lendir atau darah dan penyakit infeksi lainnya. Efek samping dari pengguna antibiotik bakteri menjadi kebal, mual, muntah, diare, gigi kuning/rusak dan gangguan kulit.

(http://www.diskopjatim.go.id/lens)

Sebagian ibu menggunakan antibiotik pada masa kehamilan sesuai dengan dosis 93,33\% dan masih ada ibu yang tidak menggunakan antibiotik sesuai dengan resep sebesar $10 \%$.

Penggunaan antibiotik dapat menyembuhkan penyakit, terutama penyakit infeksi tetapi antibiotik dapat berbahaya bila tidak digunakan dengan tepat. Sesuai anjuran dokter yang tertera pada resep obat untuk ibu hamil dan menyusui, bayi/balita, pasien gagal ginjal, gagal hati, harus gunakan dengan rekomendasi dari dokter. (http://www.diskopjatim.go.id/lensa)

Sebagian besar ibu $(66,66 \%)$ tidak mengetahui kegunaan antibiotik pada masa kehamilan dapat menyebabkan perubahan gigi anak. Menurut pendapat Gracianti Afrilina (2006). banyak faktor yang mempengaruhi terjadinya pewarnaan pada gigi tetap yang menyebabkan perubahan warna gigi menjadi kecoklatan bahkan abu-abu. Antibiotik tetrasiklin merupakan salah satu jenis obat yang dapat menyebabkan kelainan warna gigi, yang terjadi bila terlalu banyak dikonsumsi selama masa pembentukan gigi. Ibu hamil dan menyusui sebaiknya tidak minum obat antibiotik jenis tetrasiklin, begitu pula dengan anak-anak di bawah usia tujuh tahun. Karena pada usia tersebut masih berlangsung pembentukan gigi tetap.

Sebagian besar ibu mengetahui pengaruh penggunaan antibiotik pada masa kehamilan sebesar 100\%. Pendapat jane chumbley (2003). Para praktisi kesehatan gigi dan medis sangat menyadari berbagai resiko yang mengancam gigi bayi dalam kandungan akibat pemberian antibiotik yang mengandung tetrasiklin pada ibu hamil. Hal ini dapat menyebabkan perubahan warna pada gigi bayi yang sedang terbentuk saat itu, tetapi baru akan terlihat ketika gigi tersebut tumbuh

\section{Kesimpulan}

1. Tingkat pengetahuan ibu-ibu tentang penggunaan antibiotik pada masa kehamilan terhadap pewarnaan gigi anak balita di kelurahan Lau Cih Kecamatan Medan Tuntungan dengan tingkat pengetahuan yang baik adalah 20 orang $(66,66 \%), 10$ orang $(33,33 \%)$ memiliki pengetahuan sedang dan tidak ada orang 
ibu-ibu yang memiliki tingkat pengetahuan buruk (0\%).

2. Para ibu $(83,3 \%)$ pernah mengkonsumsi antibiotik tetapi belum mengetahui bahwa Antibiotik dapat mengakibatkan pewarnaan gigi anak balita.

\section{Saran}

1. kepada petugas kesehatan memberikan penyuluhan kepada masyarakat khususnya ibi-ibu di posyandu Lau Cih Kecamatan Medan Tuntungan tentang penggunaan antibiotik pada masa kehamilan terhadap pewarnaan gigi anak balita.

2. Kepada ibu hamil hendaknya menggunakan obat sesuai resep yang diberikan.

\section{DAFTAR PUSTAKA}

Afrilina, Gracianti, dkk. 2006. Masalah Gigi Anak dan Solusinya. Jakarta : PT. Elex Media Komputindo

Chumbely, jane, dkk. 2003. Merawat Gigi Bayi. Jakarta : Erlangga

Notoatmojo, Soekidjo. 2007. Promosi Kesehatan dan Ilmu Perilaku. Jakarta : Rineka Cipta

Notoatmojo, Soekidjo. 2002. Defenifi Pengetahuan Jakarta : Rineka Cipta

Ramadhan, Ardyan Gilang. 2010. Serba Serbi Kesehatan Gigi dan Mulut. Jakarta : Bukune

Tjay, Tan Hoan, dkk. 2002. Edisi V. Farmakologi

www.Annehira. Com, Manfaat antibiotic http://www.Artikata. Com/arti-319242-antibiotik. html,defenisiantibiotikhttp://www.diskopjatim.co.id /lensawww.sehatgroup. Web. Id /?=695-tombolokmirippanduan penyusunan KTI Poltekes Medan, 2006 